Photogallery

\title{
Another diner sits at the banquet: evidence of a possible population outbreak of Culcita sp. (Agassiz, 1836) in Maldives
}

\section{Enrico MONTALBETTI ${ }^{\star 1,2}$, Luca SAPONARII,2, Simone MONTANO ${ }^{1,2}$, and Davide SEVESO ${ }^{1,2}$}

${ }^{1}$ MaRHE Center (Marine Research and High Education Centre), Magoodhoo Island, Faafu Atoll, Maldives

${ }^{2}$ Dipartimento di Scienze dell'Ambiente e del Territorio (DiSAT), Università di Milano-Bicocca

* Corresponding author: E. Montalbetti

E-mail: enrico.montalbetti@unimib.it

Communicated by Saki Harii (Editor-in-Chief)

Keywords Coral reef, Corallivory, Seastar, Maldives

The cushion seastars Culcita spp. are facultative corallivores that can feed on different coral species. In Maldives, they showed general preference for small coral colonies and recruits belonging to the genera Pocillopora and Pavona (Montalbetti et al. 2019). Contrary to what has been described for the most investigated coral predator Acanthaster spp., large population densities of Culcita spp. have never been recorded to date, since the cushion seastar abundances have been reported to be less than 0.5 individuals per $100 \mathrm{~m}^{2}$ on average, although these numbers can slightly vary from one place to another (Bruckner and Coward 2018). However, during different surveys performed from May to October 2018 in Faafu Atoll, Republic of Maldives, an unusual high density of cushion seastars was observed. Three belt-transects of $50 \mathrm{~m} \times 4 \mathrm{~m}$ were performed on each reef in order to count the number of specimens within a unit area. In particular, a density of 42 seastars per $600 \mathrm{~m}^{2}$, thus meaning 1 specimen every $14.3 \mathrm{~m}^{2}$, was observed on the reef flat ( $\sim \mathrm{m}$ depth) of Magoodhoo (Fig. 1A), an inhabited island located on the south-eastern region of the atoll rim whose reef is approximately

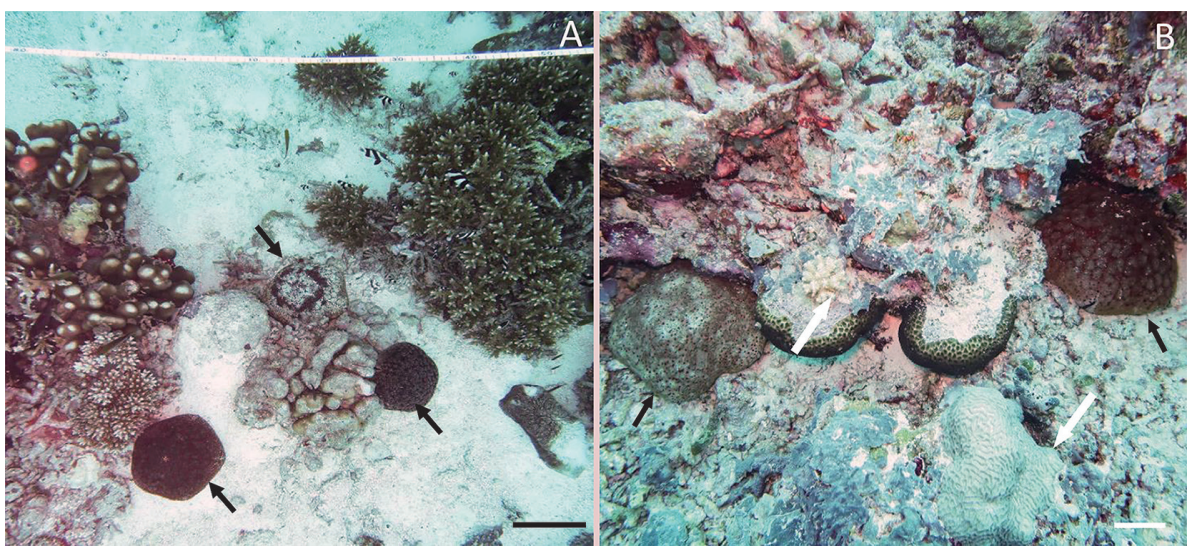

Fig. 1 (A) View of three specimens of Culcita sp. grouped together (indicated by black arrows) found on a reef flat in Magoodhoo island. Scale bar $15 \mathrm{~cm}$. (B) Detail of two individuals found close to eaten coral colonies (indicated by white arrows). Scale bar $5 \mathrm{~cm}$. 
$3 \mathrm{~km}$ long and $1.55 \mathrm{~km}$ wide. Other 37 seastars per $600 \mathrm{~m}^{2}$, meaning 1 seastar every $16.2 \mathrm{~m}^{2}$, were counted on the reef slope ( $15 \mathrm{~m}$ depth) of Adhangau, an uninhabited island with a relatively smaller reef than the one of Magoodhoo, measuring $1.3 \mathrm{~km}$ in length and $250 \mathrm{~m}$ in width. These specimens were often found forming groups of several individuals close to small coral colonies presenting scars due to seastars predation (Fig. 1B). These colonies appeared white in color, without any living tissue, and often covered by a thick layer of mucus. These observations, along with other evidences previously reported from other reefs in Maldives (Bruckner and Coward 2018), meet the criteria of most of the definitions of Acanthaster spp. outbreak used to define these phenomena (Pratchett et al. 2014) and at the same time definitely exceed usual abundances of cushion seastars found on coral reefs (Bruckner and Coward 2018). For these reasons, we hypothesized that the large numbers of individuals of Culcita sp. described here may indicate the occurrence of a population outbreak. Since the cushion seastar shows selective feeding, both from a dimensional and a qualitative point of view, preferring small colonies of few coral genera (Montalbetti et al. 2019), the impact of a possible population outbreak could severely affect the structure and the resilience of coral reefs. Thus, we suggest more detailed studies to better understand the population dynamics and clarify the possibility of an outbreak of the cushion seastar in Maldives.

\section{References}

Bruckner AW, Coward G (2018) Abnormal density of Culcita schmideliana delays recovery of a reef system in the Maldives following a catastrophic bleaching event. Mar Freshwater Res 70 (2): 292-301

Montalbetti E, Saponari L, Montano S, Maggioni D, Dehnert I, Galli P, Seveso D (2019) New insights into the ecology and corallivory of Culcita sp. (Echinodermata: Asteroidea) in the Republic of Maldives. Hydrobiologia 827: $353-$ 365

Pratchett MS, Caballes CF, Rivera-Posada JA, Sweatman HPA (2014) Limits to understanding and managing outbreaks of crown-of-thorns starfish (Acanthaster spp.). Ocean Mar Bio 52: 133-200

Received: 3 March 2019/Accepted: 19 May 2019

(C) Japanese Coral Reef Society 